\title{
Estimasi Kanal Sistem OFDM pada Kanal Fading Rayleigh dengan Metode Piecewise Linear
}

\author{
Walid Maulana Hadiansyah* \\ Teknik Telekomunikasi, Fakultas Teknik Elektro, Institut Teknologi Telkom Surabaya; \\ * Correspondence: walid@ittelkom-sby.ac.id
}

\begin{abstract}
Abstrak: Transmisi data kecepatan tinggi menjadi sorotan masyarakat saat ini karena semakin banyak masyarakat menggunakan teknologi nirkabel pita lebar untuk memenuhi kebutuhan seharihari. Long Term Evolution (LTE) masih menjadi teknologi eksisting yang memanfaatkan sistem Orthogonal Frequency Division Multiplexing (OFDM) sebagai solusi penghematan bandwidth. Untuk mempertahankan kualitas data dari distorsi, maka dibutuhkan teknik estimasi kanal. Dengan mengetahui hasil estimasi kanal, maka akan didapatkan solusi untuk meminimalisasi efek distorsi. Respon impuls diasumsikan berupa kanal fading Rayleigh. Estimasi kanal yang dipakai adalah metode estimasi Piecewise Linear dengan 2 slope. Serangkaian penelitian yang bisa dilakukan setelah estimasi kanal adalah estimasi efek doppler, minimalisasi interferensi antar-simbol, dan efisiensi serta optimalisasi sistem. Dari hasil simulasi menggunakan program Matlab dengan 100 kali iterasi, dapat diambil kesimpulan bahwa semakin besar Signal to Noise Ratio (SNR), semakin kecil error yang terjadi. Nilai rata-rata error estimasi dari $\mathrm{SNR}=9-40 \mathrm{~dB}$ adalah $2.4 \%-38.2 \%$.
\end{abstract}

Kata Kunci: Estimasi Kanal, LTE, Matlab, OFDM, SNR.

\section{Pendahuluan}

Perkembangan teknologi telekomunikasi nirkabel pita lebar semakin lama semakin banyak diperbincangkan. Kebutuhan akan transmisi data kecepatan tinggi begitu dibutuhkan dalam melayani kebutuhan masyarakat sehari-hari. Teknologi telekomunikasi yang sudah dipakai sejak lima tahun terakhir di Indonesia ini adalah teknologi LTE, di mana memanfaatkan sistem OFDM yang memungkinkan untuk melipatgandakan kecepatan transmisi data hingga beberapa puluh Mbps dengan tetap mempertahankan Quality of Service (QoS) tetap baik [1]. OFDM distandarisasikan sebagai skema untuk Digital Audio Broadcasting (DAB) dan Digital Video Broadcasting (DVB) [2]. DAB merupakan standar penyiaran radio digital yang banyak digunakan di negara Eropa dan Asia. Sedangkan DVB merupakan standar sistem televisi digital yang sudah diakui secara internasional dan dikelola oleh konsorsium industri. OFDM diklaim jauh lebih tangguh daripada generasi sebelumnya, termasuk dalam efisiensi penggunaan bandwidth disebabkan penggunaan multi-carrier yang saling ortogonal [3]. Dengan multi-carrier yang saling ortogonal tersebut, juga membuat sistem lebih tahan terhadap interferensi antar frekuensi.

Untuk mentransmisikan data yang berukuran besar, diperlukan kecepatan data yang tinggi sehingga didapatkan QoS yang baik. Namun, apabila data ditransmisikan dengan kecepatan tinggi, maka akan menyebabkan delay sebagai akibat dari adanya multipath fading. Multipath fading merupakan fluktuasi level sinyal di penerima yang terjadi karena ada lebih dari satu kanal propagasi. Akibatnya, ada error antara sinyal yang diterima dengan sinyal yang dikirim. Sistem OFDM menjadi solusi dari adanya efek multipath fading karen multi-carrier yang saling ortogonl sebagaimana dijelaskan pada paragraf sebelumnya [4]. Di awal pengenalan OFDM, para peneliti masih memakai penggunaan Discrete Fourier Transform (DFT) dan Inverse Discrete Fourier Transform (IDFT) sebagai pengganti bank generator sinyal sinusoidal dan demodulator. Untuk mengurangi kompleksitas algoritma, maka para peneliti menggunakan Fast Fourier Transform (FFT) dan Inverse Fast Fourier 
Transform (IFFT). Penggunaan FFT dan IFFT pada OFDM akan mempermudah dalam implementasi pada perangkat keras [5].

Kendala yang ditemui dalam transmisi data kecepatan tinggi adalah kesalahan atau error deteksi simbol di penerima. Error ini diakibatkan oleh simbol-simbol yang berdekatan mengalami interferensi antar simbol atau Inter Symbol Frequency (ISI). Untuk bisa memprediksi bahkan mereduksi dampak ISI, maka diperlukan penambahan Guard Interval (GI) pada pemancar, serta channel estimator atau equalizer pada penerima dengan harapan bisa mengkompensasi distorsi kanal tersebut [6]. Oleh karena itu, pada jurnal ini akan dijelaskan tentang performansi estimasi kanal pada sistem OFDM melalui simulasi program Matlab pada kanal fading Rayleigh. Beberapa peneliti telah mencoba untuk melakukan estimasi kanal. D.V. Bhimsing menjelaskan filter Wiener bisa menghasilkan estimasi lebih baik di kanal fading Rayleigh daripada Rician [7]. A. Farzamnia menggunakan metode Least Square (LS) dan Minimum Mean Square Error (MMSE) untuk mendapatkan estimasi kanal, dan menunjukkan bahwa metode MMSE lebih baik daripada LS [8]. Pada jurnal ini, peneliti menggunakan metode Piecewise Linear dengan 2 slope sebagai metode alternatif untuk melakukan estimasi kanal.

\section{Metode}

Modulasi digital yang sering digunakan pada sistem OFDM adalah BPSK, QAM, dan QPSK [9]. Pada pemodelan sistem OFDM sebagaimana pada Gambar 1, data input biner yang dibangkitkan dimodulasi QPSK. Kemudian masuk ke blok serial to paralel dan disisipkan simbol pilot di setiap jalur paralel-nya. Setiap jalur paralel akan diawali oleh 1 baris pilot dan beberapa baris data. Sebelum dipancarkan, sinyal masuk ke IFFT sehingga sub-carrier menjadi saling ortogonal. CP ditambahkan untuk menghindari terjadinya ISI karena $\mathrm{CP}$ berperan sebagai ruang penahan antara 2 simbol yang saling berurutan. Selain itu, CP mengubah konvolusi linear menjadi konvolusi cyclic, sehingga subcarrier akan tetap ortogonal dan tidak terjadi Inter Carrier Interference (ICI) [10]. Data diubah menjadi paralel to serial, masuk ke transmiter dan melewati kanal multipath fading Rayleigh mobileto-fixed Zheng Xiao II [11]. Sebelum masuk ke penerima, data terkena noise AWGN. Untuk mengekstraksi pilot, maka data diubah dari serial to paralel, harus melepaskan $\mathrm{CP}$, dan masuk ke blok FFT. Setelah simbol pilot didapatkan, maka proses terakhir adalah mengestimasi kanal dengan metode Piecewise Linear 2 slope.

Proses terakhir pada penelitian ini adalah menganalisis hasil estimasi kanal. Estimasi kanal menyatakan prediksi analisis untuk mengetahui karakteristik kanal berdasarkan data seragam yang pancarkan oleh transmiter. Estimasi kanal nantinya akan dipakai oleh peneliti untuk proses penelitian selanjutnya. Jadi respon impuls yang didapatkan adalah respon impuls hasil estimasi, bukan respon impuls yang sebenarnya. Analisis terhadap ICI dan ISI biasanya dilakukan setelah selesai mengestimasi kanal. Susunan pilot yang telah disisipkan ke simbol-simbol OFDM menjadi petunjuk bagi peneliti untuk melakukan estimasi kanal. Piecewise Linear dengan 2 slope merupakan salah satu algoritma estimasi kanal yang sering digunakan pada sistem OFDM [12]. Gambar 2 menunjukkan bagaimana metode estimasi ini bekerja. Slope ada di dalam setiap simbol pilot OFDM. Respon impuls hasil estimasi dapat didekati berbentuk garis dengan konstanta yang konstan sepanjang respon impuls kanal pada $\mathrm{h}$ middle.

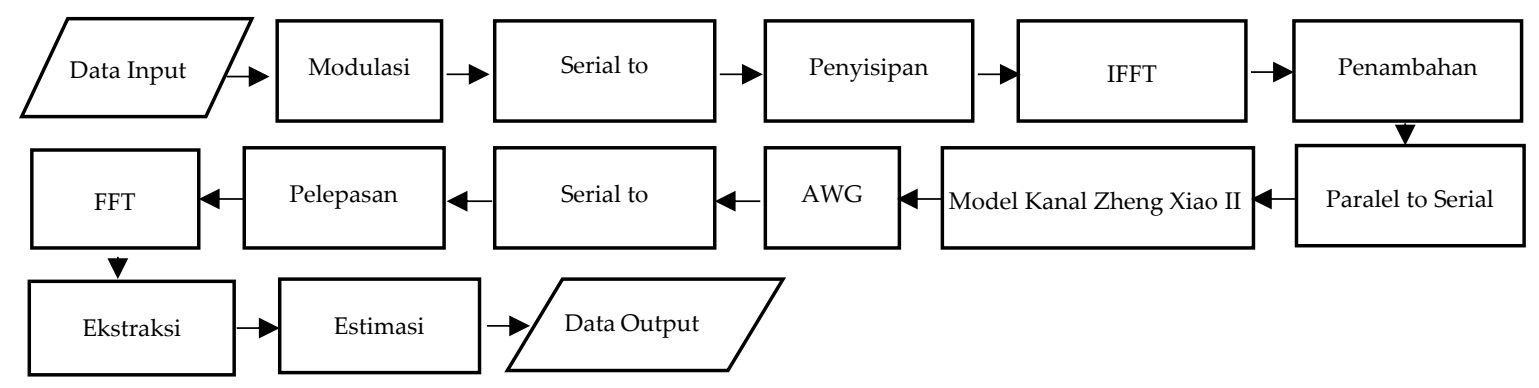

Gambar 1. Flowchart Estimasi Kanal 


$$
h_{i}(k)=h_{(N / 2)-1}(k)+(i+1-N / 2) \cdot l_{k} \cdot T_{s}
$$

di mana $h_{i}(k)$ merupakan respon impuls kanal hasil estimasi, $T_{s}$ adalah periode simbol subcarrier, $l_{k}$ adalah konstanta slope, $h_{(N / 2)-1}(k)$ adalah $\mathrm{h}$ middle, dan $i$ adalah contoh satu simbol pilot OFDM yang diambil.

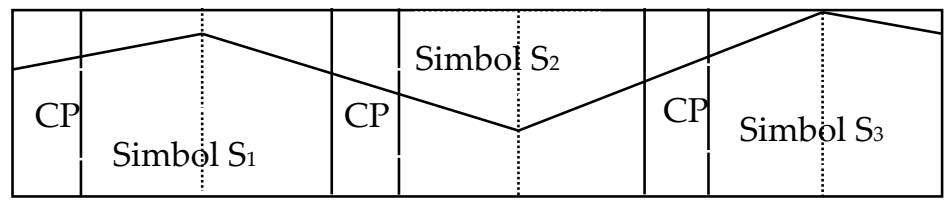

Gambar 2. Piecewise Linear dengan 2 Slope [12]

\section{Hasil}

Pada bab ini dijelaskan hasil penelitian yang dilakukan pada simulasi. Gambar 3, dapat dilihat bahwa sinyal setelah melalui proses IFFT, antar subcarrier akan saling ortogonal. Gambar tersebut merepresentasikan ortogonalitas pada domain frekuensi. Dikatakan saling ortogonal karena subcarrier $\mathrm{m} 1=\mathrm{m} 2=\mathrm{m} 3, \ldots, \mathrm{m} 63$.

Gambar 4 menunjukkan sinyal informasi yang mengandung $\mathrm{CP}$, sebelum dan sesudah terkena AWGN pada 1 simbol OFDM. Dengan adanya noise tersebut, maka mulai terjadi error sinyal antara sinyal yang dikirim dengan sinyal yang diterima. Gambar 5 merupakan grafik probabilitas error modulasi QPSK pada kanal AWGN. Dari grafik tersebut tampak bahwa SER selalu lebih besar daripada BER, dengan selisih yang konstan. Hal ini menunjukkan bahwa meskipun simbol modulasi-nya error, 1 bit dalam 1 simbol modulasi belum tentu salah. Sebagaimana dijelaskan dalam teori bahwa dalam setiap simbol modulasi diwakili oleh 2 bit. Sehingga energi 1 simbol sama dengan 2 kali energi bit. Jika dihitung, maka selisih energi simbol dan energi bit adalah sebesar log 2 dalam logaritmik. Sedangkan pada modulasi BPSK, 1 simbol modulasi diwakili oleh 1 bit, sehingga energi simbol sama dengan energi bit.

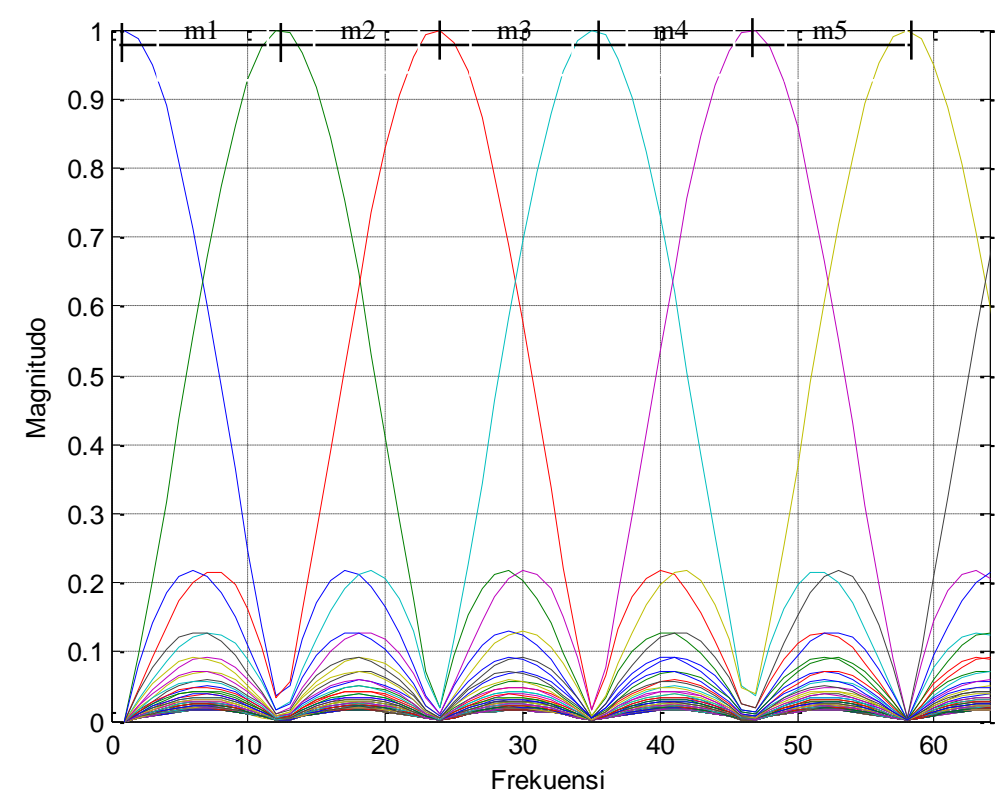

Gambar 3. Ortogonalitas Antar Sub-carrier Dalam Domain Frekuensi 


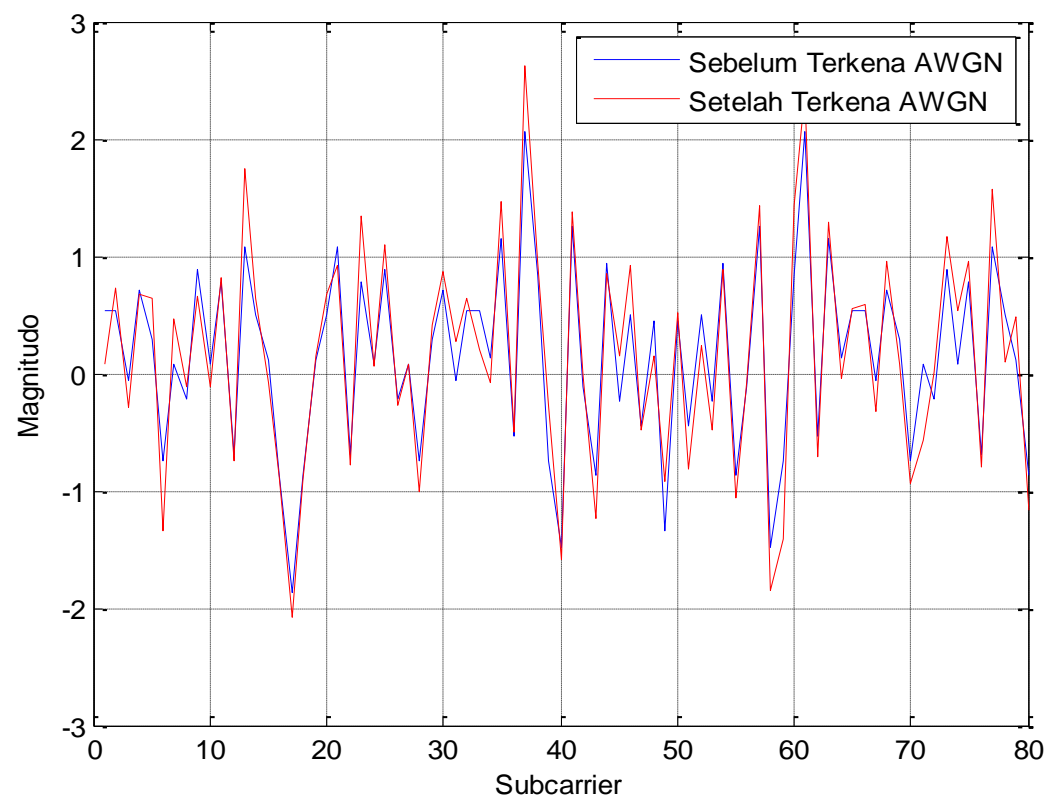

Gambar 4. Proses Penambahan CP pada 1 Simbol OFDM

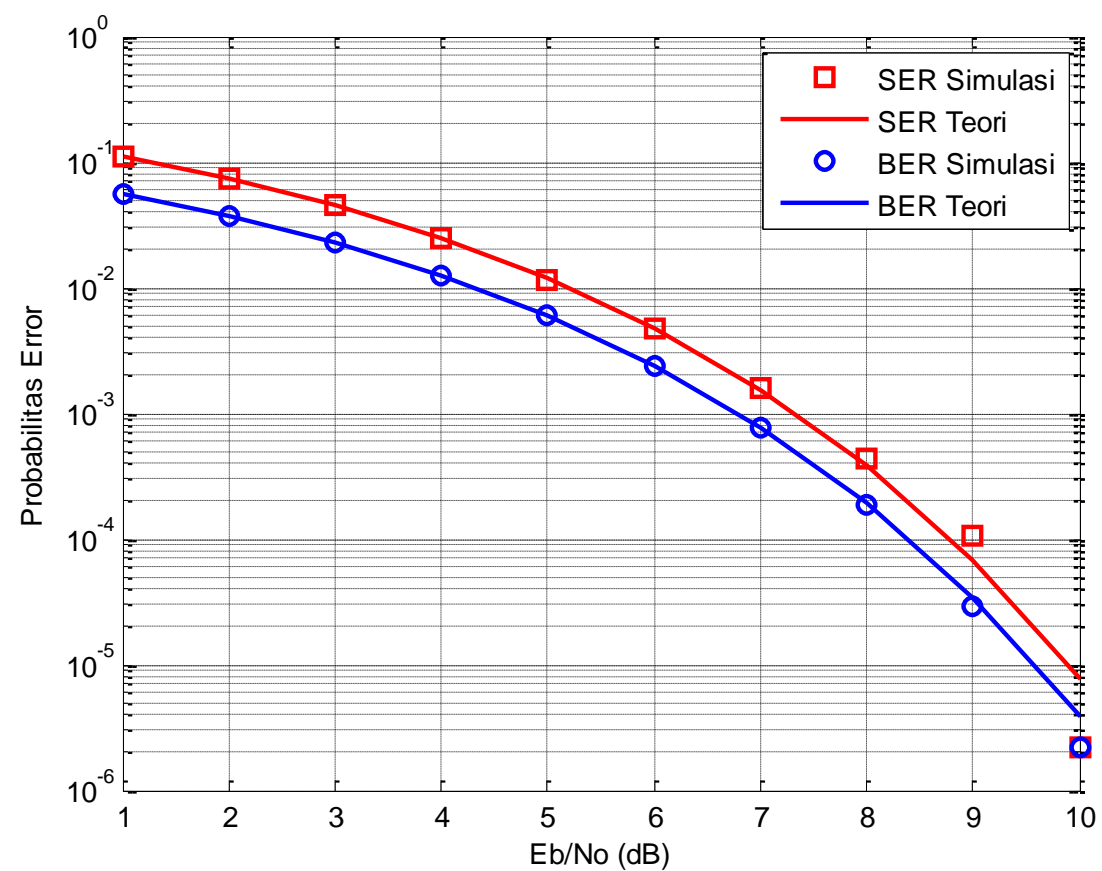

Gambar 5. Probabilitas Error Modulasi QPSK Kanal AWGN

Simulasi yang dilakukan untuk kanal multipath fading menggunakan model kanal ITU-R Vehicular M. 1225, 1997. Pada model tersebut, terdapat 6 tap dengan delay spread dan gain kanal yang berbeda-beda. Gambar 6 menunjukkan grafik BER kanal multipath fading Rayleigh dengan variasi jumlah tap, dan modulasi QPSK. Dari gambar tersebut terlihat bahwa grafik Rayleigh teori segaris dengan grafik 1 tap, di mana grafik 1 tap belum terdapat multipath dan tanpa delay. Tampak pula bahwa semakin banyak jumlah tap, maka semakin besar nilai probabilitas bit error-nya. Karena selisih gain kanal antar tap yang berbeda-beda, maka jarak antar tap pada grafik juga berbeda-beda. Dari grafik tersebut juga dapat disimpulkan bahwa semakin besar delay spread, semakin besar pula probabilitas bit error-nya. 


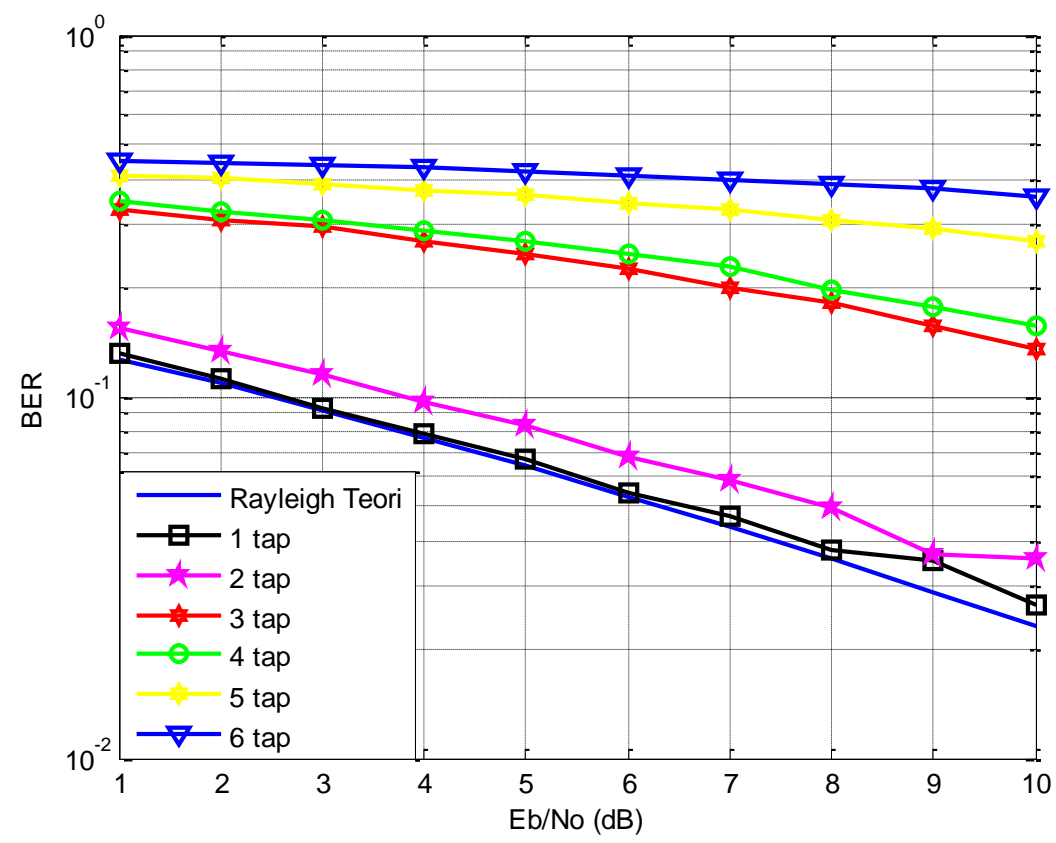

Gambar 6. BER Kanal Multipath Fading Rayleigh

Estimasi kanal pada jurnal ini, diasumsikan penerima mampu selektif memilih kanal yang paling dominan dan tanpa delay. Seperti ditunjukkan pada Gambar 7 berikut, estimasi Piecewise Linear belum dapat digunakan pada respon impuls yang memiliki delay, meskipun dengan SNR yang bagus (SNR=40). Maka dari itu, pada jurnal ini, hanya difokuskan pada path 1 tanpa delay. Gambar 8 ini menunjukkan performansi estimasi Piecewise Linear dengan beberapa nilai SNR yang berbeda. Dari hasil percobaan, dapat disimpulkan bahwa dari 81920 bit pilot yang diterima, semakin besar nilai SNR, semakin bagus pula performansi estimasi kanal Piecewise Linear 2 slope. Jika simulasi ini dianalisis lebih lanjut, maka didapatkan perbandingan rata-rata error dengan SNR=9, 20, dan 40 sebagaimana pada Gambar 9.

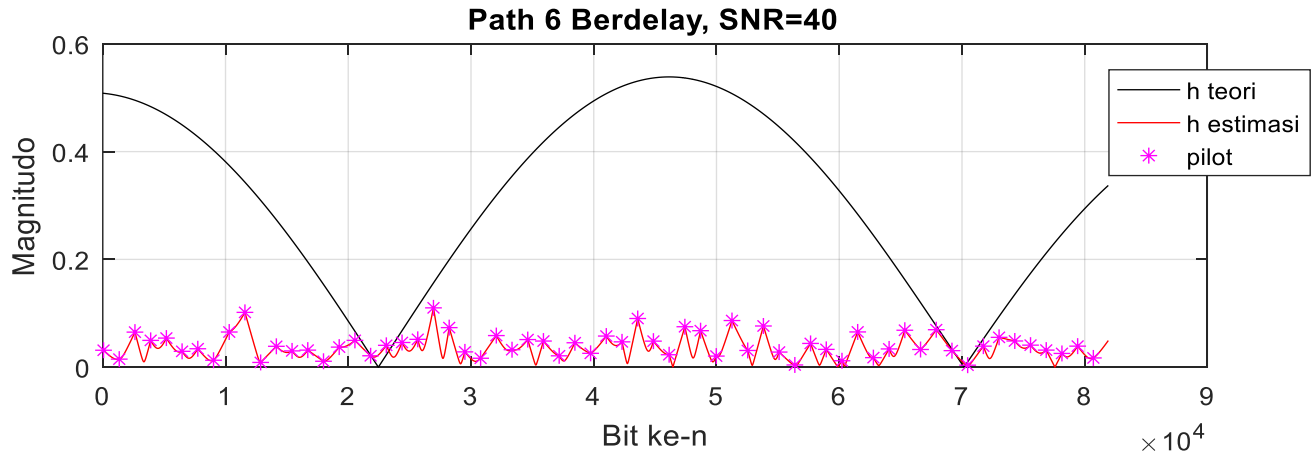

Gambar 7. Estimasi Kanal pada Path 6 Berdelay, SNR=40 

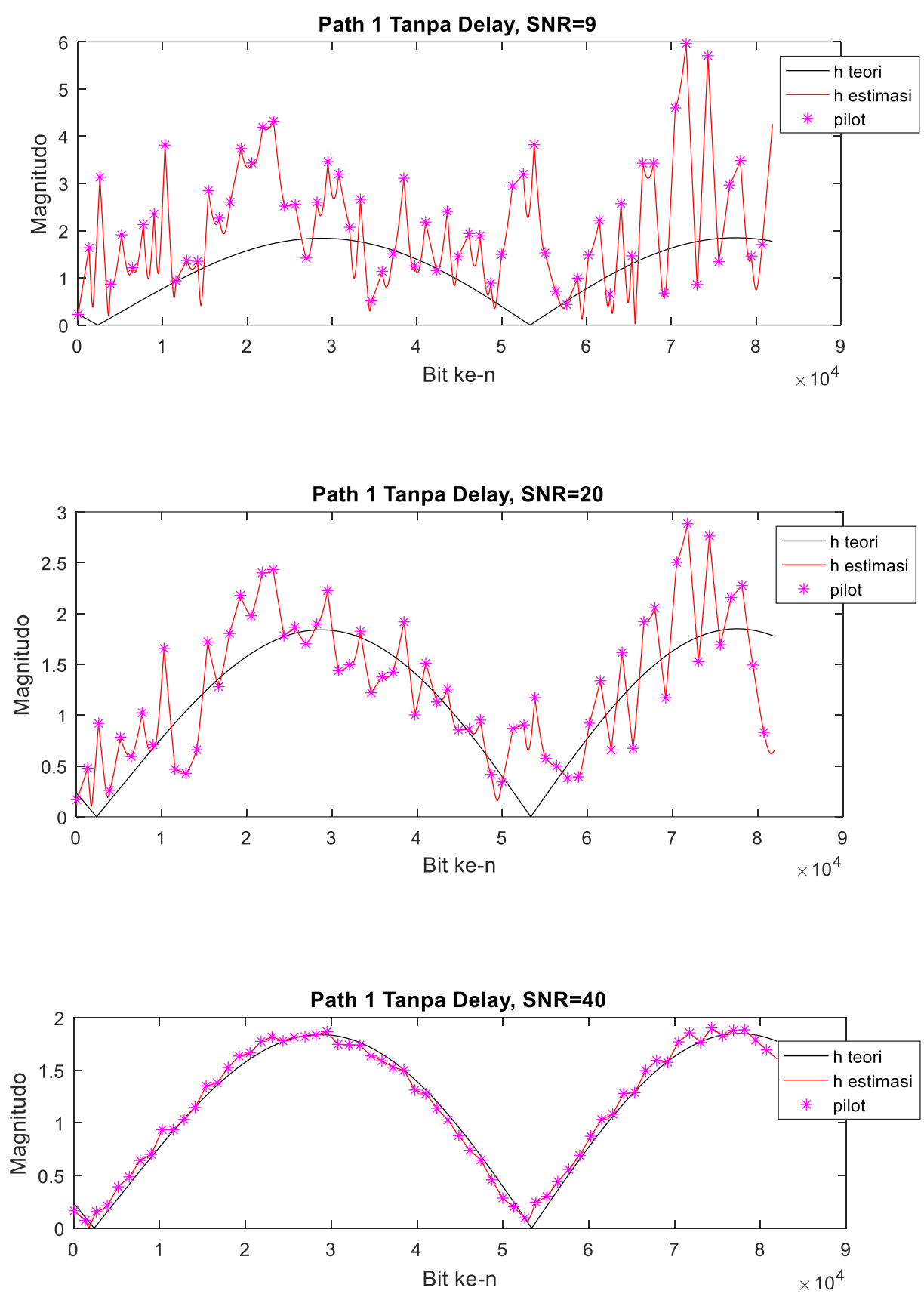

Gambar 8. Estimasi Kanal pada Path 1 dengan SNR yang Berbeda

Gambar 9 menunjukkan bahwa dari 81920 bit pilot yang diterima, error respon impuls teori (yang dibangkitkan) dengan respon impuls hasil estimasi, dengan 3 nilai SNR yang berbeda. Kesimpulan yang dapat diambil adalah semakin besar SNR, maka semakin kecil error-nya. Dengan iterasi 100 kali, peneliti mencoba mencari besaran error setiap nilai SNR, dari SNR=9 sampai SNR=40, sebagaimana pada Gambar 10 di bawah ini, dengan detail angka seperti pada Tabel 1. Simulasi diawali dari SNR=9 karena hasil estimasi untuk SNR tersebut sudah $>38 \%$. Jika lebih kecil dari nilai SNR tersebut, maka komunikasi sudah tidak layak lagi dipertahankan karena error-nya semakin besar. Simulasi diakhiri dengan $\mathrm{SNR}=40$ karena jika diperbesar akan menghasilkan estimasi yang semakin mendekati 0 . 


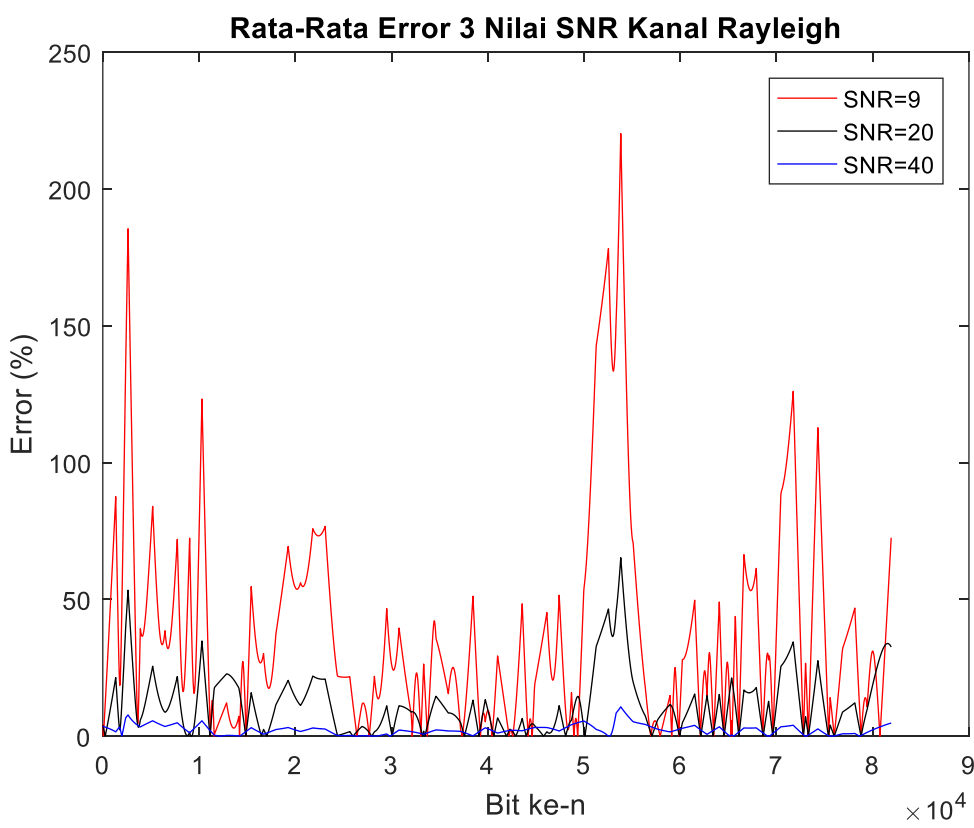

Gambar 9. Rata-Rata Error 3 Nilai SNR

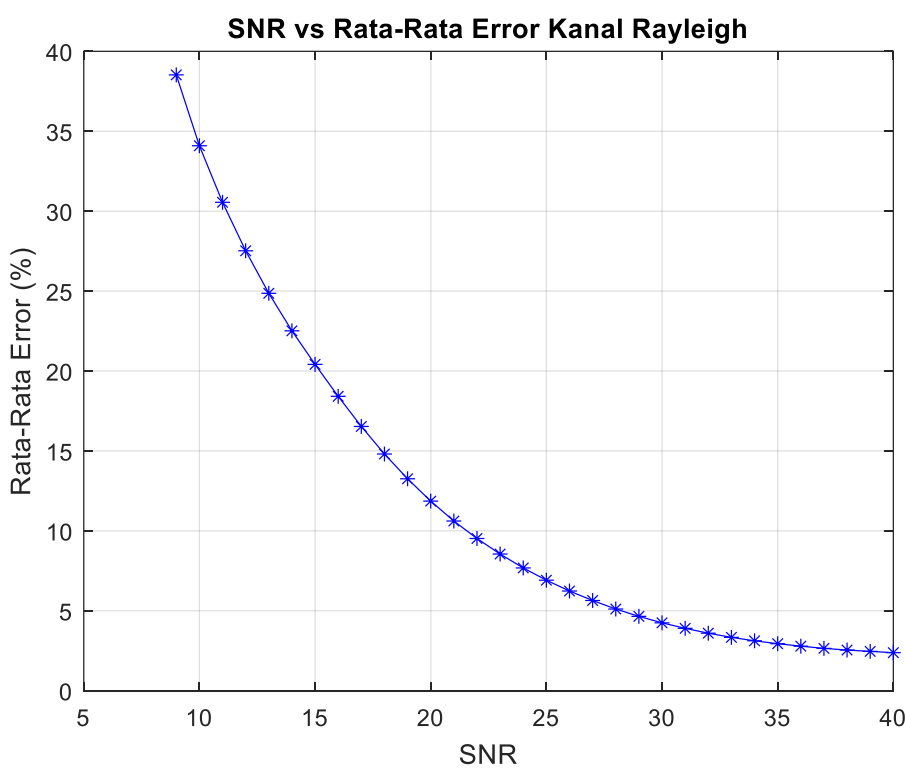

Gambar 10. Grafik Perbandingan Rata-Rata Error Terhadap SNR

Tabel 1. Rekapitulasi Error dan SNR

\begin{tabular}{cccccccc}
\hline SNR & Error (\%) & SNR & Error (\%) & SNR & Error (\%) & SNR & Error (\%) \\
\hline 9 & 38.17905694 & 17 & 15.18604463 & 25 & 6.379344254 & 33 & 3.242376671 \\
\hline 10 & 33.60407007 & 18 & 13.62057985 & 26 & 5.781381081 & 34 & 3.054456267 \\
\hline 11 & 29.73366575 & 19 & 12.20200333 & 27 & 5.25558596 & 35 & 2.899030503 \\
\hline 12 & 26.39113394 & 20 & 10.92431881 & 28 & 4.79448012 & 36 & 2.765782638 \\
\hline 13 & 23.48235012 & 21 & 9.773611737 & 29 & 4.390129352 & 37 & 2.660805587 \\
\hline 14 & 20.96825586 & 22 & 8.751677739 & 30 & 4.041622051 & 38 & 2.564018247 \\
\hline 15 & 18.80630264 & 23 & 7.848628961 & 31 & 3.734252694 & 39 & 2.485044166 \\
\hline 16 & 16.90887801 & 24 & 7.062459779 & 32 & 3.470325258 & 40 & 2.416995496 \\
\hline
\end{tabular}




\section{Kesimpulan}

Dengan melakukan simulasi pada Matlab, dapat diambil kesimpulan bahwa estimasi kanal Piecewise Linear dengan 2 slope memiliki keakuratan yang baik. Dari 100 kali iterasi setiap SNR, tampak bahwa semakin besar nilai SNR, maka semakin kecil error estimasi kanalnya. Dengan menguji pada $S N R=40$, rata-rata error yang terjadi hanya $2,4 \%$. Penelitian ke depannya adalah bisa menguji kehandalan estimasi tersebut pada respon impuls yang lain seperti model kanal mobile-tomobile, maupun kanal fading Rician.

\section{Referensi}

1. F. Ouyang. "Orthogonal Frequency Division Multiplexing (OFDM)". Digital Communication for Practicing Engineers. John B. Anderson, Ed. Canada: John Wiley \& Sons, 2020.

2. W.M. Hadiansyah, M. Hikmiyah, Y. Moegiharto, I. Anisah. "Analisis Pengaruh Reduksi Peak to Average Power Ratio (PAPR) dengan Teknik Selected Mapping (SLM) Terhadap Efisiensi Spektrum pada Sistem OFDM". Jurnal Ilmiah Bidang Teknologi Informasi dan Komunikasi, Vol. 4(2), 2019.

3. M.N. Drakshayini, A.V. Singh. "A Review on Reconfigurable Orthogonal Frequency Division Multiplexing (OFDM) System for Wireless Communication". 2nd International Conference on Applied and Theoretical Computing and Communication Technology (iCATccT), 2016.

4. M. He, M. Jin, Y. Li. Youming. "Blind Spectrum Sensing of OFDM Signals Under Multipath Fading Channels". 24th Asia-Pacific Conference on Communications (APCC), 2018.

5. G. Waichal, A. Khedkar. "Performance Analysis of FFT Based OFDM System and DWT Based OFDM System to Reduce Inter-carrier Interference". International Conference on Computing Communication Control and Automation, 2015.

6. A. Bannour, M. A. Matin. "Algebraic Space-Time (ST) Codes: An Overview". Coding for MIMO-OFDM in Future Wireless Systems, London: Springer International Publishing, 2015.

7. D.V. Bhimsing, A.C. Bhagali. "Performance of Channel Estimation and Equalization in OFDM System". IEEE International Conference on Power, Control, Signals and Instrumentation Engineering (ICPCSI), 2017.

8. A. Farzamnia, N.W. Hlaing, M.K. Haldar, J. Rahebi. "Channel Estimation for Sparse Channel OFDM Systems using Least Square and Minimum Mean Square Error Techniques". International Conference on Engineering and Technology (ICET), 2017.

9. A.M Jaradat, J.M. Hamamreh, H. Arslan. "Modulation Options for OFDM-Based Waveforms: Classification, Comparison, and Future Directions". IEEE Access, 2019.

10. M.S. El-Bakry, H.A. El-Shenawy, A.E.A. Ammar. "A Symbol Time Compression for ICI Reduction in High Mobility OFDM Systems". 29th International Conference on Microelectronics (ICM), 2017.

11. Y.R. Zheng, C. Xiao. "Simulation Model with Correct Statistical Properties for Rayleigh Fading Channels". IEEE Transactions on Communications, 2003.

12. Xu. K, “Project Report: Piecewise Linear Models for ICI Reduction in OFDM Channel Estimation”, 2003. 